\title{
Conservation management of small core areas: key to survival of a Critically Endangered population of Irrawaddy river dolphins Orcaella brevirostris in Indonesia
}

\author{
Daniëlle Kreb and Budiono
}

\begin{abstract}
Indonesia's only freshwater dolphin is the facultative Irrawaddy river dolphin Orcaella brevirostris in the Mahakam River in East Kalimantan, Borneo. To clarify the status of this Critically Endangered subpopulation we carried out a series of surveys from early 1999 until mid 2002 on abundance, habitat use, population dynamics and threats. Our estimates of total population size were 33-55 dolphins (95\% confidence limits 31-76) based on direct counts, strip-transect analysis, and Petersen and Jolly-Seber mark-recapture analyses of photo-identified individuals. Mean minimum annual birth and mortality rates were similar, i.e. 13.6 and $11.4 \%$, and no changes in abundance $>8 \%$ were detected over 2.5 years. Dolphins died mainly from entanglement in gill-nets (73\% of deaths). The dolphins' main habitat includes confluence areas between the main river and tributaries or lakes. Dolphins make intensive daily use of these confluences, moving up and downstream over an
\end{abstract}

average length of $10 \mathrm{~km}$ of river and within a $1.1 \mathrm{~km}^{2}$ area. These areas are also important fishing grounds and subject to intensive motorized boat traffic. Sixty-four percent of deaths (1995-2001) with known location $(n=36)$ occurred in these areas. Interviews with local residents revealed a generally positive attitude towards the establishment of protected areas for this subpopulation. Because of the dolphins' dependence on areas that are also used intensively by people, primary conservation strategies should be to increase local awareness and introduce alternative fishing techniques.

Keywords Freshwater ecosystem management, habitat preferences, Indonesia, Irrawaddy river dolphin, Orcaella brevirostris, population dynamics, threats.

This paper contains supplementary material that can only be found online at http:/ /journals.cambridge.org

\section{Introduction}

River dolphins and porpoises are amongst the world's most threatened mammal species. Their habitat has been highly modified and degraded by human activities, often resulting in dramatic declines in their abundance and range (Reeves et al., 2000). Protection of freshwater dolphins and their habitat is a major challenge because river systems are utilized for transport, fishing and industrial processes. Rivers are also affected by forest fires, which are more likely to occur near rivers because these areas are easily accessible to people (Fuller \& Fulk, 1998). Fires, along with illegal logging practices, probably increase sedimentation rates (Anon., 2000)

Daniëlle Kreb (Corresponding author) Institute for Biodiversity and Ecosystem Dynamics, Zoological Museum, University of Amsterdam, P.O. Box 94766, 1090 GT Amsterdam, The Netherlands.

E-mail yk-rasi@samarinda.org

Budiono Yayasan Konservasi RASI (Conservation Foundation for Protection of Rare Aquatic Species of Indonesia), P.O. Box 1105, Samarinda, Kalimantan Timur, Indonesia.

Received 9 February 2004. Revision requested 10 June 2004. Accepted 13 August 2004. with consequent disruption of aquatic ecosystems (Mackinnon et al., 1997). The facultative freshwater river dolphin Orcaella brevirostris is found in shallow, coastal waters of the tropical and subtropical Indo-Pacific and in three major river systems: the Mahakam in East Kalimantan, Indonesian Borneo, the Ayeyarwady in Myanmar, and the Mekong passing through Vietnam, Cambodia and Laos (Stacey \& Arnold, 1999). Preliminary studies have indicated that these river populations each consist of $<100$ individuals (Kreb, 2002; Smith et al., 2003). Based on data we collected during 1999 and 2000, the Red List status of the Mahakam freshwater population was changed from Data Deficient to Critically Endangered (IUCN, 2004). In Indonesia the species is commonly and locally referred to as Irrawaddy dolphin and pesut, respectively.

Since 1990 the species has been fully protected by law in Indonesia and is the adopted symbol of East Kalimantan Province. A 2-month preliminary study in 1997 revealed the sighting rate in the middle segment of the Mahakam River, believed to have the highest dolphin densities, was low (0.06 individuals per km; Kreb, 1999). To examine and monitor the status of the population in the Mahakam River, and to identify threats and develop 
a rationale for conservation action, a detailed study was carried out from February 1999 to August 2002. Here we present the results of this study, an analysis of the species' habitat preferences and population dynamics, examine the threats to the population, and make recommendations for future conservation activities.

\section{Study area}

The Mahakam is one of the major river systems of Borneo (Fig. 1). The regional climate is characterized by a dry season from July to October and a wet season from November to June (MacKinnon et al., 1997). The river runs for $c .800 \mathrm{~km}$ from its origin in the Müller Mountains to the coast. Rapids upstream of Long Bagun, c. $600 \mathrm{~km}$ from the coast, prevent dolphins from ranging further upstream. Three major lakes, several major tributaries and many smaller swamp lakes are connected to the main river system in the middle Mahakam (180-375 km from the coast). These lakes are important fish-spawning grounds and replenish the main river seasonally, and consequently there is intensive fishing in the area, with an annual catch of 25,000-35,000 tonnes since 1970 (MacKinnon et al., 1997). Coal mining and logging occur along the entire length of the Mahakam River, and especially along its tributaries. A large gold mining company is located in the upper Mahakam River, together with several small-scale, illegal gold mines. Infrastructure is poorly developed in East Kalimantan and the Mahakam River is the main transport system.

\section{Methods}

\section{Field methods}

We searched the Mahakam River from the coastal delta to the upper rapids (600 $\mathrm{km}$ from the coast) by boat from February 1999 until August 2002 for a total of 8,925 km $(837 \mathrm{~h})$, and observed river dolphins for a total of $549 \mathrm{~h}$ ( $4 \mathrm{~h}$ of which were in the Mahakam Delta rather than the river proper). We conducted 12 extensive surveys in six periods, covering the entire distribution range (average survey duration $10 \pm$ SD 2 days) during all types of water levels (high, medium and low, increasing and decreasing) to investigate distribution patterns and annual recruitment, and estimate abundance using three methods: strip transects, direct counts and markrecapture techniques through photo-identification (described in detail in Kreb, 2002 \& in press). In each extensive survey we used 15 strip transects (where the width of the river was the strip width) in the main river and tributaries and 2 line transects (where transect width is based on perpendicular sighting distances) in Melintang and Semayang Lakes. Each transect could be completed within 1 day. Six intensive surveys (average duration $12 \pm$ SD 3 days) were conducted in areas of high dolphin density to investigate preferred habitats and to locate dolphin groups for assessment of daily home ranges (Fig. 1).

To monitor abundance and locate dolphin groups during both extensive and intensive surveys, the river was scanned from 12-16 m motorized boats (12-21 hp) at an average speed of $10 \mathrm{~km} \mathrm{~h}^{-1}$. The observation team consisted of three observers: two front and one rear. Average observation time during the extensive monitoring surveys was one hour per sighting, with a total observation effort of $545 \mathrm{~h}$. During this time a total of 2,074 photographs were taken of dolphin dorsal fins. For each sighting, duration, location, group behaviour, size and composition were noted, and environmental data (depth, clarity, surface flow rate, temperature, $\mathrm{pH}$ and type of river section: bend, straight or confluence area) were collected. On average five times per day similar samples were collected from random locations at fixed times, and type of river section was recorded every $15 \mathrm{~min}$.

To assess daily home ranges 58 groups were followed for a total of $321 \mathrm{~h}$, for $5.5 \mathrm{~h}$ per day on average (range $1.5-13 \mathrm{~h}$ ), using a motorized canoe with a $5 \mathrm{hp}$ outboard engine, maintaining an average distance of $50 \mathrm{~m}$ from any dolphins. In addition, land-based observations were made in the confluence area of Muara Pahu (Fig. 1), c. $300 \mathrm{~km}$ from the coast, which was frequented daily by various dolphin groups. On average 5 sequential days (32 days in total) of land-based observations were made by two observers, who overlooked the area from 7-10 m above the water surface (depending on water levels) during six survey periods for a total of $286 \mathrm{~h}$. When a group of dolphins was sighted we recorded group size and composition (Kreb, in press), changes in group composition, and time spent in the area.

Residents and fishermen $(n=258)$ in six areas were interviewed using questionnaires (Appendix 1) to determine knowledge of dolphins and attitudes towards their conservation. Respondents were questioned separately to ensure independence of data.

To assess minimum annual birth rates between November 2000 and November 2001, the total number of newborns were counted during five surveys, with an average gap of 2.5 months between surveys. We categorized individuals as newborns, defined as $<1$ month old, if they: (1) exhibited an awkward manner of swimming and surfacing, (2) spent all their time in close proximity to an adult, and (3) were $<1 / 2$ the average length of an adult, following Bearzi et al. (1997). Newborns were assumed to be different from those encountered in any earlier survey.

The number of dead dolphins was determined from our observations and from semi-structured interviews with $c .450$ fishermen, during the preliminary survey in 


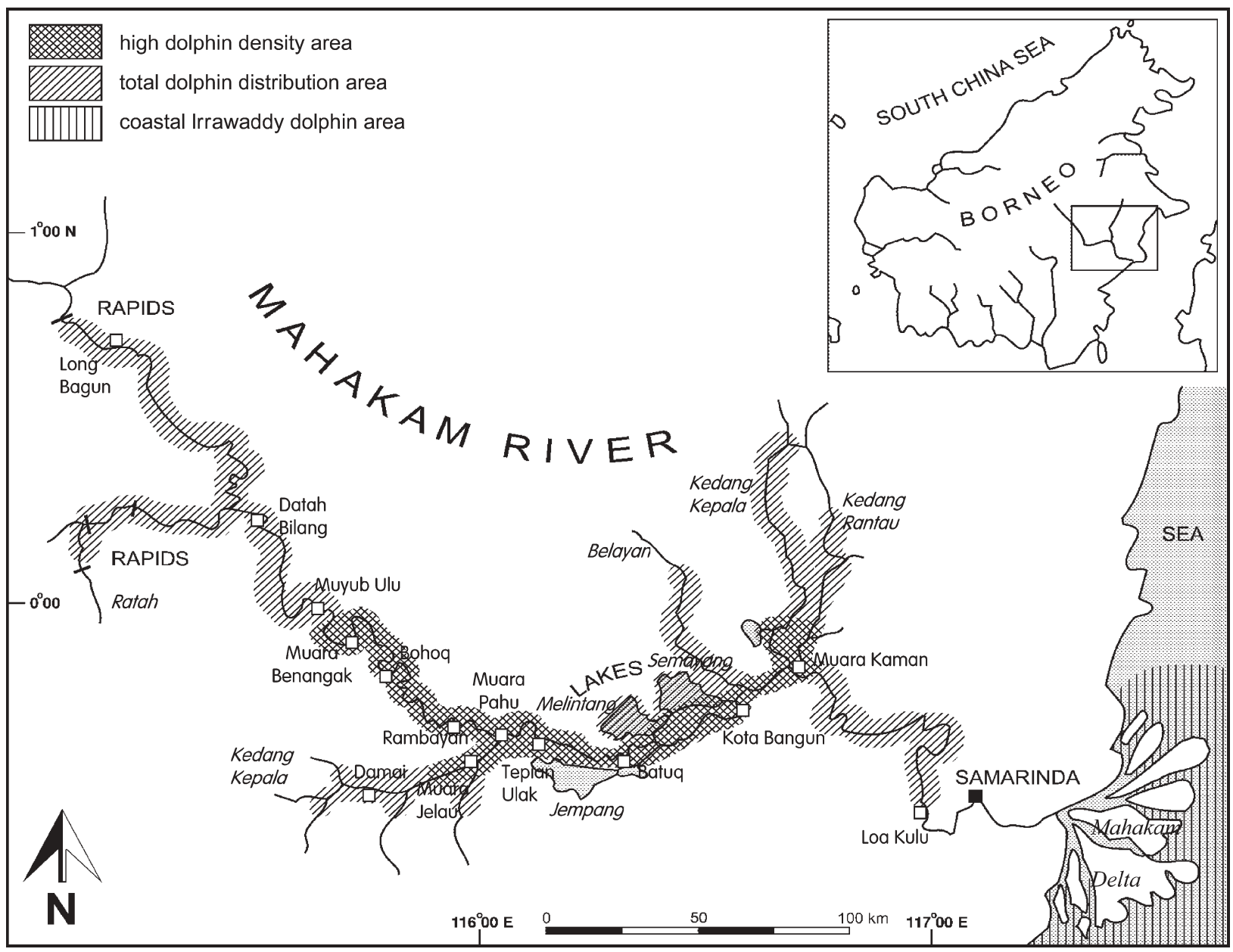

Fig. 1 The study area of the Mahakam River (rectangle on inset indicates location in Borneo), with total dolphin distribution area, areas of high dolphin density, and the coastal Irrawaddy dolphin area (see text for details). Delimitation of the coastal dolphin area was based on observations and interviews.

1997 and during surveys from February 1999 to August 2002. Information collected during the 258 questionnaire interviews confirmed some of this information and also provided further information on dead dolphins. Mortality was traced back to 1995 . Incomplete or untrustworthy accounts with missing locality, date, or traceable eyewitnesses were disregarded.

Dolphin reactions towards different types of boats were tested by comparing surfacing frequencies of dolphin groups in the presence and absence of different types of boats (see Kreb \& Rahadi, in press, for a detailed description of this method).

\section{Analysis}

To assess dolphin densities the river was divided into seven areas, in each of which there had been at least one dolphin sighting. The total sightings made in each of these areas during 10 of the 12 extensive surveys (during two of the surveys not all seven areas were covered because water conditions were unsuitable) were compared using a $\chi^{2}$ test. Sightings in tributaries within $1 \mathrm{~km}$ of the confluence were considered main river sightings. Sighting rates, densities and abundance estimates from strip transects and direct counts were calculated using the formula in Kreb (2002). As no sightings were made in any of the lakes during these extensive surveys, analysis of the line transects was not required. Estimates of mean abundance (with coefficient of variation, CV) of two replicated surveys within each survey period were averaged to obtain the mean population size and CV over all six survey periods. Abundance was also estimated for each water level condition, combining different years, by averaging the estimates of each replicated survey. This was done as there was no trend in abundance (see Results), and no difference between abundance estimates 
from replicated surveys within the same time period or in abundance estimates from surveys conducted in different periods but at similar water level conditions. Because all sightings from the rear of the boat $(n=9)$ were associated with the dolphins' positions in river bends, no detection correction factor was used to calculate abundance and associated CV; rear sightings were directly included in the abundance estimates. As there was no seasonal variation in group size (see Results) this did not need to be taken into consideration in the calculation of the $\mathrm{CV}$.

Abundance was also separately estimated, using both the Jolly-Seber and Petersen mark-recapture methods, based on 728 identifiable dorsal fin pictures (Kreb, in press). Mean group size was based on all sightings made during nine of the 12 extensive surveys that covered the entire distribution range. Groups were considered separate if they joined after $>15$ min of observation of the first encountered group, or if a group split during observation time. To detect any trend in abundance, regression analysis was applied to the natural logarithm of five mean strip transect and direct count abundance estimates, which were derived from 5 different survey periods over a 2.5 year period with $c$. 6-month intervals (early 1999 until mid 2001). In each survey period the mean estimates were derived from two surveys, i.e. one from heading upstream and the other from heading downstream. Statistical power was calculated using the linear regression programme TRENDS (Gerrodette, 1993). The same analysis was used to detect any trend in mortality over 1995-2001.

Random environmental samples were compared with samples collected at dolphin locations, at each water level, using a two sample $t$-test, prior to which a twotailed F-test was applied to test for homogeneity of variance (which was equal for all comparisons). The number of dolphin sightings, at each water level, in straight stretches, river bends and confluences in the main river were compared using a $\chi^{2}$ test. Every 15 min observers noted if the boat was within $100 \mathrm{~m}$ of a river bend or confluence or in a straight stretch; the relative abundance of these was examined using a $\chi^{2}$ test. Yates correction factor was applied in cases where $\mathrm{df}=1$. To identify the year-round importance of a confluence area, the numbers of identified dolphins were compared between different water levels using a $\chi^{2}$ test. To test if seasonal differences in dolphin abundance were a result of differences in photo-identification effort, the correlation between the number of pictures obtained and number of identified dolphins was tested using the Product Moment Correlation Coefficient.

Daily home ranges were estimated by measuring the distance between the two most widely separated sightings of the focal group. The mean annual birth rate was estimated by dividing the mean annual number of newborns by the population estimate derived from the Petersen method (this estimate was used because it had high precision but was least biased). The mean annual mortality rate was estimated by dividing the mean annual number of known dead dolphins by the population estimate derived from the Petersen method.

\section{Results}

\section{Abundance and distribution}

During the 12 extensive surveys we made 92 sightings of Irrawaddy dolphins in the Mahakam River. The sightings were confined to the area between Muara Kaman (c. $180 \mathrm{~km}$ from the coast) and Datah Bilang (c. $480 \mathrm{~km}$ from the coast) and to the tributaries Belayan, Kedang Rantau, Kedang Kepala, Kedang Pahu and Ratah, and Semayang Lake. The 195-km length of the main river from Muara Kaman to Muara Benangak, c. $375 \mathrm{~km}$ from the coast, had the highest dolphin densities (Fig. 1). Based on both sightings and interviews with fishermen, dolphins occur from c. $90 \mathrm{~km}$ upstream from the coast, at Loa Kulu, to $c .600 \mathrm{~km}$ upstream at the rapids past Long Bagun, including several tributaries and two lakes (Fig. 1). There were significant differences in sightings between eight $40-\mathrm{km}$ lengths of river $\left(\chi^{2}=35.91, \mathrm{df}=7, \mathrm{P}<0.01\right)$ (Table 1$)$. The three areas where most sightings were made include several confluence areas with tributaries and lakes.

Variations in abundance in the river and its tributary at different water levels are given in Table 2. At medium water levels sightings per $\mathrm{km}$ in the main river and tributaries are similar, whereas at high water level sightings are higher in the main river than in the tributaries. At rising high water levels (data not tabulated as coverage of the area during this period is incomplete) the lowest mean sighting rate (0.03 dolphins $\mathrm{km}^{-1}$ ) was recorded in the main river, indicating that dolphins had moved upstream into the tributaries. At low water levels dolphins were not sighted in the tributaries of the middle Mahakam (except for a group of four dolphins trapped between two rapids at low water level in the upper tributary since 1999).

Four sightings of Irrawaddy dolphins in and near the Mahakam delta were offshore at low tide, and one sighting was made $10 \mathrm{~km}$ upstream from the delta at high tide. The mean salinity of 22 ppt (Table 3) measured at dolphin locations in the delta is associated with brackish waters. According to interviews with fishermen the most inshore occurrence is at high tide c. $20 \mathrm{~km}$ upstream from the coast. As coastal dolphins have not been sighted or reported to move further upstream than this and only enter the delta at high tide, we consider them to be separate from the Mahakam River population, which appears to be isolated in the river. 
Table 1 Number of dolphins per km, newborns sighted, observed mating events and recorded deaths, and priority areas for conservation (lower numbers indicate higher priority) in $40 \mathrm{~km}$ lengths of the Mahakam River.

\begin{tabular}{|c|c|c|c|c|c|}
\hline $40-\mathrm{km}$ river survey segments ${ }^{1}$ & No. per km & No. newborns & Mating events & Deaths $^{2}$ & Priority area \\
\hline Muara Kaman - Kota Bangun & 0.13 & & & 12 & 2 \\
\hline Kota Bangun - Batuq & 0.16 & 1 & & 1 & 3 \\
\hline Batuq - Tepian Ulak & 0.10 & & 1 & 1 & 5 \\
\hline Tepian Ulak - Rambayan - Muara Jelau & 0.31 & 8 & 1 & 13 & 1 \\
\hline Rambayan - Bohoq & 0.04 & & & 2 & 6 \\
\hline Bohoq - Muara Muyub Ulu & 0.04 & & & & 6 \\
\hline Ratah & 0.12 & & & 1 & 4 \\
\hline Muara Jelau - Damai & 0.04 & & & 1 & 6 \\
\hline
\end{tabular}

${ }^{1}$ See Fig. 1

${ }^{2}$ Dolphins that died in the survey area between 1995-2001; in addition, 5 dolphins died outside the survey area and 2 died at unknown locations.

${ }^{3}$ Proposed conservation areas (1-3) are confined to small areas within these river stretches based on locations of frequent sighting (Table 9).

Table 2 Number of transects, total transect length and mean transect width in each of three river sections (Fig. 1) surveyed at three water level conditions, with numbers of dolphin groups sighted, mean group size, density by river length and area, and mean dolphin abundance (with coefficient of variation, CV).

\begin{tabular}{|c|c|c|c|c|c|c|c|c|}
\hline Survey area & $\begin{array}{l}\text { No. } \\
\text { transects }\end{array}$ & $\begin{array}{l}\text { Total } \\
\text { length }(\mathrm{km})\end{array}$ & $\begin{array}{l}\text { Mean transect } \\
\text { width }(\mathrm{m})\end{array}$ & $\begin{array}{l}\text { No. of } \\
\text { groups }\end{array}$ & $\begin{array}{l}\text { Mean group } \\
\text { size }\end{array}$ & No. $\mathrm{km}^{-1}$ & No. $\mathrm{km}^{-2}$ & $\begin{array}{l}\text { Mean } \\
\text { abundance (CV) }\end{array}$ \\
\hline \multicolumn{9}{|c|}{ Middle main river ${ }^{1}$} \\
\hline High water & 6 & 414 & 200 & 12 & 4.6 & 0.13 & 0.67 & $28(24)$ \\
\hline Medium water & 9 & 621 & 200 & 16 & 4.5 & 0.12 & 0.58 & $23(27)$ \\
\hline Low water & 12 & 828 & 200 & 28 & 4.3 & 0.15 & 0.73 & $30(9)$ \\
\hline \multicolumn{9}{|c|}{ Middle tributary ${ }^{1}$} \\
\hline High water & 2 & 152 & 43 & 2 & 4.6 & 0.06 & 1.4 & $5(0)$ \\
\hline Medium water & 3 & 228 & 43 & 7 & 4.5 & 0.14 & 3.2 & $12(62)$ \\
\hline Low water & 4 & 304 & 43 & 0 & 4.3 & 0 & 0 & $0(0)$ \\
\hline \multicolumn{9}{|l|}{ Upper tributary $^{2}$} \\
\hline High water & 2 & $33^{2}$ & 75 & 2 & 4.6 & - & - & $5(0)$ \\
\hline Medium water & 3 & $33^{2}$ & 75 & 3 & 4.5 & - & - & $5(0)$ \\
\hline Low water & 4 & $33^{2}$ & 75 & 4 & 4.3 & - & - & $4(0)$ \\
\hline
\end{tabular}

${ }^{1}$ Cross-shaded area in Fig. 1

${ }^{2}$ From mouth of tributary to rapids; the dolphins sighted there, however, occupy a river length of only $2 \mathrm{~km}$ beween two rapids, and therefore densities have not been calculated.

Table 3 Environmental characteristics of the various sections of the Mahakam River (Fig. 1), determined at medium water level, and total fish production in 1999.

\begin{tabular}{|c|c|c|c|c|c|c|}
\hline \multirow[b]{2}{*}{ River section } & \multicolumn{4}{|c|}{ Mean of random samples \pm SD } & \multirow[b]{2}{*}{$\begin{array}{l}\text { Bottom } \\
\text { substrate }\end{array}$} & \multirow[b]{2}{*}{$\begin{array}{l}\text { Total fish } \\
\text { production } \\
(\text { ton })^{2}\end{array}$} \\
\hline & Depth (m) & $\begin{array}{l}\text { Surface flow } \\
\left(\mathrm{m} \mathrm{s}^{-1}\right)\end{array}$ & $\begin{array}{l}\text { Clarity }(\mathrm{cm}) \text { or } \\
\text { mean salinity } \\
(\mathrm{ppt})^{1}\end{array}$ & $\begin{array}{l}\text { Width }(\mathrm{m}) \text { or } \\
\text { mean distance } \\
\text { off-/inshore }(\mathrm{km})^{1}\end{array}$ & & \\
\hline Lower & $15 \pm 5$ & $0.8 \pm 0.4$ & $30 \pm 9$ & $370 \pm 65$ & Mud & 0 \\
\hline Middle & $17 \pm 6$ & $0.8 \pm 0.3$ & $26 \pm 9$ & $200 \pm 54$ & Mud & 23,201 \\
\hline Upper & $12 \pm 7$ & $1.1 \pm 0.3$ & $20 \pm 10$ & $161 \pm 48$ & Sand, cobbles & $0^{3}$ \\
\hline Middle tributary & $9 \pm 4$ & $0.7 \pm 0.5$ & $22 \pm 15$ & $41 \pm 14$ & Mud & - \\
\hline Upper tributary & $12 \pm 8$ & $0.8 \pm 0.0$ & $18 \pm 0.0$ & $75 \pm 12$ & Rocks & - \\
\hline Lakes & $2 \pm 0.3$ & 0 & $56 \pm 9$ & - & Mud & - \\
\hline Delta & $5 \pm 4$ & - & $22 \pm 9^{1}$ & $\begin{array}{l}3 \mathrm{~km} \text { offshore - } \\
10 \mathrm{~km} \text { inshore }\end{array}$ & Mud, sand & 6,931 \\
\hline
\end{tabular}

${ }^{1}$ Only applies to the delta

${ }^{2}$ Data representing direct catch (excluding aquaculture), for market sale within dolphin habitat, from the Kutai Fisheries Department. Data for tributaries and large lakes are not available separately and have therefore been combined with the middle river section to which they are connected.

${ }^{3}$ Fish production data in the upper river section only available to $425 \mathrm{~km}$ upstream, whereas dolphin distribution is to $560 \mathrm{~km}$ upstream. 
Table 4 Number of transects, total transect length, number of dolphin groups sighted, mean group size and mean number of groups sighted per survey, with dolphin abundance (with coefficient of variation, CV, and confidence limits, CL) calculated using two methods, i.e. strip transect analysis and direct counts (see text for details), at three water levels and combined.

\begin{tabular}{llllllll}
\hline $\begin{array}{l}\text { Water level } \\
\text { (no. surveys) }\end{array}$ & $\begin{array}{l}\text { No. } \\
\text { transects }\end{array}$ & $\begin{array}{l}\text { Total transect } \\
\text { length }(\mathrm{km})^{1}\end{array}$ & $\begin{array}{l}\text { No. groups } \\
\text { sighted }\end{array}$ & $\begin{array}{l}\text { Mean group } \\
\text { size }\end{array}$ & $\begin{array}{l}\text { Mean no. groups } \\
\text { sighted per survey }\end{array}$ & $\begin{array}{l}\text { Abundance (strip } \\
\text { transects) (CV, CL) }\end{array}$ & $\begin{array}{l}\text { Abundance (direct } \\
\text { counts) (CV, CL) }\end{array}$ \\
\hline High (2) & 10 & 599 & 16 & 4.6 & 8 & $37(17,1-94)$ & $36(12,1-74)$ \\
Medium (3) & 15 & 882 & 26 & 4.5 & 8.7 & $40(19,21-58)$ & $33(8,26-40)$ \\
Low (4) & 20 & 1165 & 32 & 4.3 & 8 & $34(9,30-39)$ & $32(2,31-33)$ \\
Combined & 45 & 2646 & 74 & 4.4 & 8.2 & $37(15,33-41)$ & $33(8,31-35)$ \\
\hline
\end{tabular}

${ }^{1}$ Only including length of those sections where dolphins were sighted

Total mean abundance estimates for the entire dolphin population in the Mahakam River derived from striptransect analysis and direct counts made during the nine extensive monitoring surveys that had complete coverage of the total survey area are 37 and 33, respectively (Table 4). Mark-recapture analyses based on photoidentification gave total estimates of 55 dolphins ( $\mathrm{CV}=$ $6 \%$; 95\% confidence limits, CL, 44-76) with Petersen's method, and 48 (CV $=15 \%$; 95\% CL 35-63) with the Jolly-Seber method. The total number of dolphins identified throughout the study period was 59 .

Regression analysis of the natural logarithm of the mean strip-transect abundance estimates of five survey periods at c. 6-month intervals showed a non-significant $1 \%$ increase in abundance during the study period $(b=0.01, t=0.52, \mathrm{df}=3, \mathrm{P}>0.05)$. There was also no change in direct count abundance estimates for the same period $(b=0.001, t=0.18, \mathrm{df}=3, \mathrm{P}>0.05)$. Power analysis revealed that in order to detect a $5 \%$ change with $90 \%$ power and mean $\mathrm{CV}$ of 13 or $6 \%$ (mean of the CVs of replicated strip transect or direct count estimates in each survey period) 28 strip samples or seven count samples would be needed. In our study period (with five samples) only changes as large as 20\% (strip-transect estimates) or $8 \%$ (direct counts) would have been detected with $90 \%$ power.

\section{Population dynamics}

The dolphin population consisted on average of $61 \%$ adults, 30\% juveniles and 9\% calves and neonates (Table 5). The mean group size observed during the

Table 5 Number of adults, juveniles, and calves and neonates in three surveys, each at a different water level, in 2000 or 2001.

\begin{tabular}{lcccc}
\hline & $\begin{array}{l}\text { Medium } \\
(2000)\end{array}$ & $\begin{array}{l}\text { High } \\
(2001)\end{array}$ & $\begin{array}{l}\text { Low } \\
(2001)\end{array}$ & Mean \\
\hline Adults & $19(58)$ & $22(61)$ & $20(63)$ & $20(61)$ \\
Juveniles & $10(3)$ & $11(31)$ & $9(28)$ & $10(30)$ \\
Calves \& neonates & $4(12)$ & $3(8)$ & $3(9)$ & $3(9)$ \\
\hline
\end{tabular}

extensive monitoring surveys was 4.4 (SD 2.2, range 1-10). Population composition and group size did not fluctuate during different water levels $(H=0.17, \mathrm{df}=2)$.

Minimum annual number of newborns during the study period was six. Newborns were observed at all water levels and in all months of the year. Birth rates of $11 \%$ per year were calculated using the Petersen estimate $(n=55)$ of population size. With six newborns per year, the minimum number of breeding females is 12 or 18 individuals if a 2- or 3-year reproduction cycle applies, respectively.

During the 3.5 year study period a minimum of 17 dolphins died unnaturally (interviews and pers. obs.). Minimum average annual mortality during the study period was $5 \pm$ SD 2 (range $=3-8$ ), which is $9 \%$ of the Petersen derived population estimate. Total mortality rates, including deaths from natural causes, are unknown.

\section{Habitat preferences and home ranges}

All freshwater fish trade comes from the middle river section (including tributaries and lakes; Table 3), which has the highest dolphin densities. For most environmental parameters and water levels there were no significant differences between random samples and samples collected at dolphin locations. Only for depth measurements at low water levels in the tributaries of the middle river section was there a significant difference in mean depth of random samples $(7.5 \mathrm{~m})$ and of samples at dolphin locations $(16.7 \mathrm{~m} ; t=2.85, \mathrm{df}=16, \mathrm{P}<0.05)$. This suggests that dolphins prefer to remain in deep water pools, such as confluence areas, during the dry season. Their dependence upon confluence areas during low-water levels is indicated in Fig. 2. At low water levels significantly more sightings occurred in these areas than in river bends $\left(\chi^{2}=8.5, \mathrm{df}=1, \mathrm{P}<0.01\right)$, in spite of the fact that river bends are significantly more numerous $\left(\chi^{2}=24.3, \mathrm{df}=1, \mathrm{P}<0.01\right)$. More than half $(54 \%)$ of the 59 dolphins photo-identified occurred in the confluence area of Muara Pahu at low water levels (Table 6). Although photographic effort was greatest at low water, 


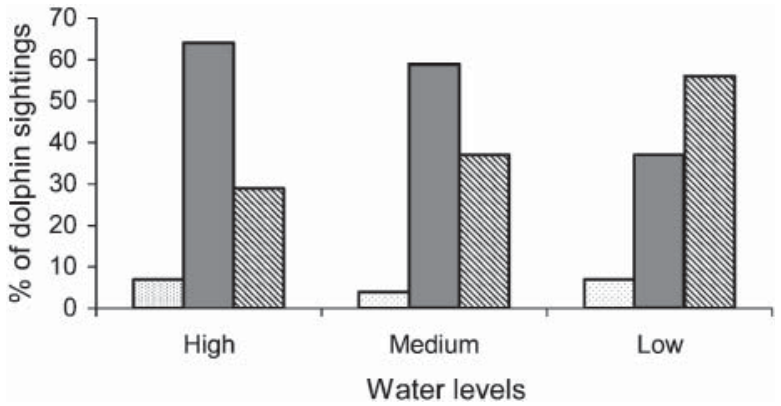

Fig. 2 Percentage of dolphin sightings at high, medium and low water levels in straight stretches of river, river bends and confluences. The relative availability of straight stretches was significantly higher than that of bends and confluences $\left(\chi^{2}=112.3, \mathrm{df}=2, \mathrm{P}<0.01\right)$, and bends were significantly more numerous than confluences $\left(\chi^{2}=24.3, \mathrm{df}=1, \mathrm{P}<0.01\right)$.

Table 6 Occurrence of photo-identified individual dolphins in the confluence area of Muara Pahu on 5 sequential days during each of four water levels in 2000 and 2001.

\begin{tabular}{lllll}
\hline & $\begin{array}{l}\text { Medium } \\
(2000)\end{array}$ & $\begin{array}{l}\text { High } \\
(2001)\end{array}$ & $\begin{array}{l}\text { Medium/low } \\
(2001)\end{array}$ & $\begin{array}{l}\text { Low } \\
(2001)\end{array}$ \\
\hline Identified dolphins & 22 & 19 & 25 & 32 \\
Identifiable pictures & 46 & 28 & 37 & 64 \\
\hline
\end{tabular}

there was no correlation between the number of pictures obtained and the number of identified dolphins $(R=0.893, \mathrm{df}=2, \mathrm{P}>0.05)$. At other water levels the number of dolphins identified in this area was still high and there were no significant differences in seasonal presence $\left(\chi^{2}=5.1, \mathrm{df}=3, \mathrm{P}>0.05\right)$.

Overall, dolphins occurred in the confluence area of Muara Pahu on average during $42 \%$ of daytime (Table 7). The highest daily occupancy was at high water levels $(65 \%)$. Dolphins still remained nearby $(<10 \mathrm{~km})$ at medium and low water levels, but they spent less time in the confluence area. On average three different groups (range 2-6) consisting of a combined mean number of 12 individuals (range 5-19), frequented the confluence area daily. Moreover, $44(75 \%)$ of the 59 photo-identified dolphins were sighted at least once in the confluence area (mean $=6$ days, $\max =17$ days of 49 photo/observation days in that area). Eight individuals were sighted exclusively within $20 \mathrm{~km}$ of the confluence area (mean number of sightings per individual $=9$, range $=2-13$ ).

The confluence area of Muara Pahu and another confluence area c. $10 \mathrm{~km}$ upstream, in the Kedang Pahu tributary, accounted for $89 \%$ of the sightings of newborns observed during boat surveys $(n=9)$ (Table 1$)$. The majority of deaths $(64 \%)$ with known location $(n=36)$ also occurred in confluence areas. Mating was observed within different groups in the confluence of Muara Pahu and at one location between Batuq and Tepian Ulak (Fig. 1).

The average daily home ranges of 27 groups, which were followed for more than 6 hours, were $10 \pm$ SD $8.6 \mathrm{~km}$ long (range 1-45 km) and $1.1 \pm \mathrm{SD} 1.8 \mathrm{~km}^{2}$ in area (range $0.1-9 \mathrm{~km}^{2}$ ). One group of six photo-identified dolphins are trapped between rapids in the Ratah River; they have been living for 3.5 years in a river segment $2 \mathrm{~km}$ long and $0.2 \mathrm{~km}^{2}$ in area.

\section{Threats}

Between 1995 and 2001, 38 deaths, mostly of adults (86\%) were recorded on the basis of interviews and two of our own observations (Fig. 3). Most dolphins (74\%) died as a result of entanglement in gill-nets with large mesh sizes $(7.5-17.5 \mathrm{~cm})$. We often observed dolphins feeding near these nets. Dolphins are also said to aid fishermen by guiding fish into their nets, and fishermen use the dolphins' feeding patterns as indicators of the location and time to set up gill-nets, and in this way increase the danger of entanglement. However, there are reports of dolphins successfully released from gill-nets by fishermen. The second major cause of death was deliberate kills $(10 \%)$, mostly in isolated areas where dolphins rarely occur. Five dolphins that incidentally died in

Table 7 Search effort for dolphins, total number of hours of sightings, and mean daily presence of dolphins in the confluence area of Muara Pahu.

\begin{tabular}{|c|c|c|c|c|c|c|c|}
\hline & \multicolumn{6}{|l|}{ Water level (year) } & \multirow[b]{3}{*}{ Total or mean } \\
\hline & \multirow[b]{2}{*}{ Medium-low (2000) } & \multicolumn{2}{|c|}{ Medium-high } & \multirow[b]{2}{*}{ High (2001) } & \multirow[b]{2}{*}{ Low (2001) } & \multirow[b]{2}{*}{ Very low (2001) } & \\
\hline & & 2000 & 2001 & & & & \\
\hline Search effort $(\mathrm{km})^{1}$ & 46.2 & 48.2 & 35.9 & 51.2 & 45.9 & 58.7 & 286.1 \\
\hline Total sightings (h) & 18.0 & 23.7 & 15.4 & 33.4 & 17.3 & 11.8 & 119.6 \\
\hline $\begin{array}{l}\text { Mean daily presence } \\
\text { (\% of daylight hours) }{ }^{2}\end{array}$ & 39 & 49 & 43 & 65 & 38 & 20 & 42 \\
\hline
\end{tabular}

${ }^{1}$ Daily search effort was from c. 7.00 until 18.00. Observation sometimes started later if morning fog obstructed the view.

${ }^{2}$ Calculated by dividing the total number of hours during which dolphins were present by the total number of hours of search. 


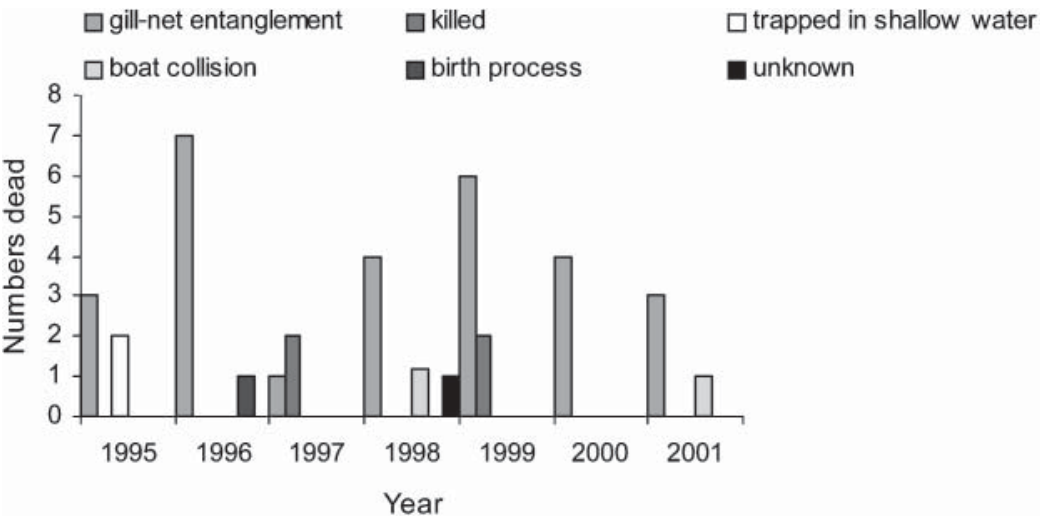

Fig. 3 Dolphin mortality from 1995 to 2001 based on reliable reports and interviews, and on our own observations. gill-nets were eaten and the skin of two was used as medicine for skin allergy (allegedly the patients' allergy disappeared).

From 1974 to 1988, 28 dolphins were legally livecaptured and taken to Jaya Ancol oceanarium in Jakarta. Two detailed local accounts of illegal captures in 1997 and 1998, of 3 and 4 dolphins respectively, were reported. Their fate and destination remain unknown. In 2002 a request for live captures was submitted to the General Directorate of Protection and Conservation of Nature (PKA) by the Regent of Central Kutai Province, East Kalimantan, for a new oceanarium along the Mahakam River (8-12 dolphins) and by Jaya Ancol Oceanarium in Jakarta (4-5 dolphins). Following intensive lobbying by local NGOs and as there has been a ban on live captures since 1990 by the Ministry of Forestry, the request was not granted.
Another identified threat was noise pollution from high-speed vessels $(40-200 \mathrm{hp})\left(\right.$ mean $=4.6$ boats $\left.\mathrm{h}^{-1}\right)$, which causes the dolphins to dive significantly longer than usual when within $\leq 300 \mathrm{~m}$ (Kreb \& Rahadi, in press). Container barges (in 2001, mean $=8.4$ boats per day) pass daily through a narrow tributary, Kedang Pahu, which is primary dolphin habitat. Dolphins always changed their direction (if swimming upstream) when they encountered barges and moved downstream ahead of the boats back to the confluence area.

\section{Conservation}

The majority of residents along the Mahakam River were positively inclined towards the dolphins, felt they needed to be protected, and agreed that protected areas needed to be established (Table 8). The following

Table 8 Summary of interviews (Appendix 1) with local residents along the Mahakam River $(n=258)$.

\begin{tabular}{|c|c|c|c|}
\hline Question & Answers & $\%$ of respondents & Explanation \\
\hline $\begin{array}{l}\text { Has the pesut brought } \\
\text { any advantages to you? }\end{array}$ & $\begin{array}{l}\text { Yes } \\
\text { No } \\
\text { Don't know }\end{array}$ & $\begin{array}{r}75 \% \\
4 \% \\
21 \%\end{array}$ & $\begin{array}{l}\text { Advantages: Indicates good fishing areas }(47 \%) \text {; indicates right time } \\
\text { \& season for fishing }(20 \%) \text {; indicates long-term rising \& decreasing } \\
\text { water levels ( } 9 \%) \text {; is enjoyable to observe }(24 \%) \\
\text { Disadvantages: Has no commercial value }(100 \%)\end{array}$ \\
\hline $\begin{array}{l}\text { Would you agree to the } \\
\text { establishment of protected } \\
\text { areas for the pesut? }\end{array}$ & $\begin{array}{l}\text { Yes } \\
\text { No } \\
\text { Don't know }\end{array}$ & $\begin{array}{r}74 \% \\
4 \% \\
22 \%\end{array}$ & $\begin{array}{l}\text { Agree, with conditions }(27 \%) \text { : No fishing ban }(59 \%) \text {; profitable to } \\
\text { residents }(4 \%) \text {; positive for development }(7 \%) \& \text { for tourism }(7 \%) \text {; } \\
\text { restricted to tributaries }(7 \%) \text {; with approval of fishermen }(4 \%) \\
\text { Disagree: Too much disturbance }(100 \%)\end{array}$ \\
\hline $\begin{array}{l}\text { Would you regret if the } \\
\text { pesut became extinct? }\end{array}$ & $\begin{array}{l}\text { Yes } \\
\text { No } \\
\text { Unrealistic }\end{array}$ & $\begin{array}{r}64 \% \\
30 \% \\
6 \%\end{array}$ & $\begin{array}{l}\text { Reasons for regret: Pride of East Kalimantan (44\%); rare mammal } \\
\text { species }(28 \%) \text {; indicator of good fishing seasons (28\%) } \\
\text { Reasons for no regret: Has no value (100\%) } \\
\text { Unrealistic: Still many dolphins \& extinction not possible }\end{array}$ \\
\hline
\end{tabular}


incident is illustrative of the goodwill of local residents. In 2002 an entire village in important dolphin habitat helped the provincial wildlife conservation department capture and transport a dolphin that was trapped in a shallow lake, which would soon fall dry, back to the main river. Afterwards villagers joined in a symbolic meal to mark their commitment to dolphin conservation; the same village had earlier helped with live captures for oceanaria. The general positive attitude towards the dolphins may be linked with the local belief that the dolphins have a human origin.

\section{Discussion}

The most important and consistent finding with respect to the Irrawaddy dolphin's distribution pattern and habitat use in the Mahakam River is its preference for confluence areas, and the small daily movements within such areas. Besides being deep, these areas are attractive to dolphins because of their high fish abundance and countercurrents, which cause fish to be momentarily trapped. Irrawaddy dolphins in the Mekong River (Stacey, 1996) and Ayeyarwady River (Smith et al., 1997), and other river dolphin species (Amazon dolphin Inia geoffrensis, McGuire \& Winemiller, 1998; Indus and Ganges dolphins Platanista gangetica gangetica and P. g. minor, Khan \& Niazi, 1989; Smith, 1993; Yangtze dolphin Lipotes vexilifer, Hua et al., 1989) also prefer confluence or deep areas with countercurrent eddies.

No historical data for dolphin abundance exist for the Mahakam River population. However, information from residents indicated a decline in most sections, although in the middle Mahakam some residents doubted that numbers had decreased or the dolphins become less visible and more shy. Mortality mostly affected adults, and birth rates may have decreased due to loss of breeding animals. The present birth rates are similar to those of the Vulnerable Amazon dolphin, which has annual pregnancy rates of 10-15\% (Martin \& Da Silva, 2000). Based on our own observations and semi-structured interviews with local residents a decline appears to have occurred during 1980-2000 in a river stretch of $120 \mathrm{~km}$, from $60 \mathrm{~km}$ until $120 \mathrm{~km}$ upstream of the mouth, which is $15 \%$ of total dolphin historical range (i.e. $820 \mathrm{~km}$ including tributaries). The range decline coincides with increased industrial activities and boat traffic and decreases in fish populations (based on fishing data for 1990-2000 from the Fisheries Department in Tenggarong).

The disappearance of dolphins from Jempang Lake and decreases in numbers in the other two lakes (confirmed by residents) is probably due to: (1) reduced depth of the lakes in the middle Mahakam area due to sedimentation (data from Environmental Controlling Body, Tenggarong) caused by deforestation of the surrounding shorelines for agriculture, and from illegal logging and forest fires, and (2) high density of gill-nets in the fishing season (pers. obs.) obstructing dolphin movements.

Threats that were also evident, although not directly observed in this study, were leaks of mercury and cyanide in 1997 from dams that retain chemical wastes from gold-mining industries, (A. Faroek, pers. comm.) and from many small-scale and illegal gold-mining operations (pers. obs.). In addition, we observed that a considerable amount of coal falls into the river because of the overloading of containers that are tugged along a tributary that is primary dolphin habitat. In this area in 2000 we observed some dolphins with altered pigmentation on parts of their bodies; it is not, however, clear whether this is a skin disease and, if so, what caused it. These pigment changes were not observed on dolphins in other areas.

Another threat is potential prey depletion due to intensive fishing with gill-nets, electricity and poison. Interviews with fishermen (Appendix 2; $n=108$ ) revealed that $48 \%$ were opposed to using electrofishing, but $43 \%$ were in favour of it. The reasons for favouring electric fishing were that fish can be caught faster and more easily. This group also believed that fish abundance is still high and unlikely to decrease.

A conservation programme, initiated in November 2000 by a local NGO, Yayasan Konservasi RASI (Conservation Foundation for the Protection of Rare Aquatic Species of Indonesia) focuses on the protection of the freshwater Irrawaddy dolphin population and its habitat in the Mahakam River. The main activities conducted since 2000 include an annual conservation/awareness campaign aimed at different sectors of society, annual monitoring of the dolphin population, socioeconomic

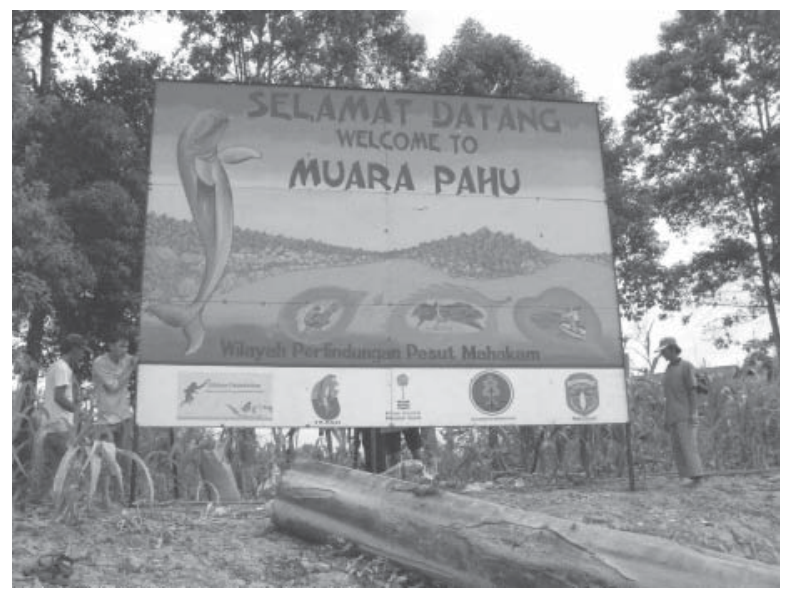

Plate 1 Erection of a welcoming billboard to indicate the major dolphin habitat in the confluence area of Muara Pahu (see Fig. 1; photograph Hari Mulyono). 
Table 9 Recommendations for protection of the freshwater ecosystem of the Mahakam River.

\begin{tabular}{ll}
\hline No. & Major recommendations \\
\hline 1 & $\begin{array}{l}\text { Establish conservation areas in the identified priority areas (Table 1): (1) The confluence area of Muara Pahu \& Kedang Pahu } \\
\text { tributary to Bolowan; (2) the confluence area of Muara Kaman \& tributary Kedang Rantau; (3) the Pela tributary \& southern part of } \\
\text { Lake Semayang (Fig. 1). }\end{array}$ \\
$2 \quad \begin{array}{l}\text { In conservation areas: (1) Set a speed limit for boats; (2) exclude large coal-carrying ships, employing smaller barges or transport } \\
\text { over land (upgrading an old, existing road). }\end{array}$ \\
$\begin{array}{l}\text { (1) Exclude gill-nets in these areas, or (2) set regulations on type of gill-nets used and on the location, season, and manner of setting; } \\
\text { (3) introduce alternative fishing techniques. Offer alternative employment options for gill-net fishermen. }\end{array}$ \\
$\begin{array}{l}\text { Strict law-enforcement by local government to attain sustainable use of available fish resources and stop illegal fishing, logging, } \\
\text { pollution and capture of dolphins. }\end{array}$ \\
$\begin{array}{l}\text { Conduct environmental awareness campaigns to increase concern for the conservation of natural resources at both the political \& } \\
\text { community level. }\end{array}$ \\
Continue to monitor the dolphin population \& the threats to it.
\end{tabular}

surveys related to fisheries, attitude assessment surveys with local communities, demarcation of an important dolphin site by placing a large billboard in Muara Pahu (Plate 1), and establishment of patrols in several villages (local fishermen who, since 2002, patrol their area and report illegal fishing activities).

If efforts are made to reduce mortality, halt habitat deterioration and protect the dolphins' food supply, survival and even recovery of this, Indonesia's only freshwater population of dolphins, could be feasible. The viability of the population remains unknown as data on the degree of inbreeding is not available. The dolphins' dependence on small and potentially manageable sites and the generally positive attitude of local residents towards the conservation of the pesut may enhance prospects for successful conservation. Protected deep water areas that are important for dolphins in the Mekong have also benefited fish populations and fishermens' livelihoods (Baird, 2001). The pesut fits the definition of a flagship species both internationally and locally; it has charisma and thus may effectively facilitate protection of other species and of the ecosystem with which it is associated (Bowen-Jones \& Entwistle, 2002). Our conservation recommendations (Table 9) would benefit the freshwater ecosystem, Irrawaddy dolphins and local people. Without establishment of protected areas, the future of Indonesia's only freshwater dolphin, and the symbol of East Kalimantan Province, will become increasingly bleak.

\section{Acknowledgements}

We thank the Indonesian Institute for Sciences (LIPI), the provincial wildlife conservation department (BKSDA) and local governments of Central- (KUKER) and West Kutai (KUBAR) for granting permission to conduct field research. All field assistants, particularly Ahang, Arman,
Karen Damayanti and Syahrani, boatsmen and respondents are gratefully thanked. Funding for fieldwork was provided by Ocean Park Conservation Foundation, Hong Kong, Martina de Beukelaar Stichting, Stichting J.C. van der Hucht Fonds, Gibbon Foundation, The Netherlands Ministry of Agriculture, Nature Management and Fisheries (PIN/KNIP), Van Tienhoven Stichting, WWF (Netherlands), Amsterdamse Universiteits Vereniging. The University of Mulawarman in Samarinda (UNMUL), Achmat A. Bratawinata, Frederick R. Schram, Peter J.H. van Bree, Thomas A. Jefferson and Vincent Nijman are thanked for their support, and Martjan Lammertink, Randall R. Reeves, Tony R. Martin, Tamara L. Mcguire and Ian G. Baird for their comments on the manuscript.

\section{References}

Anon. (2000) Illegal logging in Indonesia threatens the future of the country's forests. Oryx , 34, 73-74.

Baird, I.G. (2001) Towards sustainable co-management of Mekong River aquatic resources: the experience in Siphandone wetlands. In Siphandone Wetlands (ed. G. Daconte), pp. 89-111. CES VI, Bergamo, Italy. Bearzi, G., Notarbartolo-Di-Sciara, G. \& Politi, E. (1997) Social ecology of bottlenose dolphins in the Kvarneric (Northern Adriatic Sea). Marine Mammal Science, 13, 650-668.

Bowen-Jones, E. \& Entwistle, A. (2002) Identifying appropriate flagship species: the importance of culture and local context. Oryx, 36, 189-195.

Fuller, D.O. \& Fulk, M. (1998) Satellite Remote Sensing of the 1997-1998 Fires in Indonesia: Data, Methods and Future Perspectives. WWF-Indonesia, Jakarta, Indonesia.

Gerrodette, T. (1993) TRENDS: software for a power analysis of linear regression. Wildlife Society Bulletin, 21, 515-516.

Hua, Y., Zhao, Q. \& Zhang, G. (1989) The habitat and behaviour of Lipotes vexilifer. In Biology and Conservation of the River Dolphins (eds W.F. Perrin, R.L. Brownell Jr, K. Zhou \& J. Liu), pp. 92-98. Occasional Paper of the IUCN Species Survival Commission No. 3, IUCN, Gland, Switzerland. 
IUCN (2004) 2004 IUCN Red List of Threatened Species. IUCN, Gland, Switzerland [http:/ /www.redlist.org, accessed 7 January 2005].

Khan, K.M. \& Niazi, M.S. (1989) Distribution and population status of the Indus dolphin, Platanista minor. In Biology and Conservation of the River Dolphins (eds W.F. Perrin, R.L. Brownell Jr, K. Zhou \& J. Liu), pp. 77-80. Occasional Paper of the IUCN Species Survival Commission No. 3, IUCN, Gland, Switzerland.

Kreb, D. (1999) Observations on the occurrence of Irrawaddy dolphin, Orcaella brevirostris, in the Mahakam River, East Kalimantan, Indonesia. Zeitschrift für Säugetierkunde, 64, $54-58$.

Kreb, D. (2002) Density and abundance of the Irrawaddy dolphin, Orcaella brevirostris, in the Mahakam River of East Kalimantan, Indonesia: a comparison of survey techniques. The Raffles Bulletin of Zoology, Supplement, 10, 85-95.

Kreb, D. (in press) Abundance of freshwater Irrawaddy dolphins in the Mahakam in East Kalimantan, Indonesia, based on mark-recapture analysis of photo-identified individuals. Journal of Cetacean Research and Management.

Kreb, D. \& Rahadi, K.D. (2004) Living under an aquatic freeway: effects of boats on Irrawaddy dolphins (Orcaella brevirostris) in a coastal and riverine environment in Indonesia. Aquatic Mammals, 30, 363-375.

MacGuire, T.L. \& Winemiller, K.O. (1998) Occurrence patterns, habitat associations, and potential prey of the river dolphin, Inia geoffrensis, in the Cinaruco River, Venezuela. Biotropica, 30, 625-638.

MacKinnon, K., Hatta, G., Halim, H. \& Mangalik, A. (1997) The Ecology of Kalimantan. The Ecology of Indonesia Series 3. Oxford University Press, Oxford, UK.

Martin, A.R. \& Da Silva, V.M.F. (2000) Aspects of Status of the Boto Inia geoffrensis in the Central Brazilian Amazon. Paper SC/52/SM15, presented at 52nd Annual Meeting of the International Whaling Commission, Small Cetacean Subcommittee. 14-26 June 2000, Adelaide, Australia.

Reeves, R.R., Smith, B.D., Crespo, E.A. \& Notarbartolo di Sciara, G. (2003) Dolphins, Whales and Porpoises: 2002-2010 Conservation Action Plan for the World's Cetaceans. IUCN/SSC, Cetacean Specialist Group. IUCN, Gland, Switzerland and Cambridge, UK.

Reeves, R.R., Smith, B.D. \& Kasuya, T. (2000) Biology and Conservation of Freshwater Cetaceans in Asia. Occasional Paper of the IUCN Species Survival Commission No. 23. IUCN, Gland, Switzerland.
Smith, B.D. (1993) 1990 status and conservation of the Ganges River dolphin Platanista gangetica in the Karnali River, Nepal. Biological Conservation, 66, 159-169.

Smith, B.D., Beasley, I. \& Kreb, D. (2003) Marked declines in populations of Irrawaddy dolphins. Oryx , 37, 401.

Smith, B.D., Thant, U.P., Lwin, J.M. \& Shaw, C.D. (1997) Investigation of cetaceans in the Ayeyarwady River and northern coastal waters of Myanmar. Asian Marine Biology, 14, 173-194.

Stacey, P.J. (1996) Natural history and conservation of Irrawaddy dolphins, Orcaella brevirostris, with special reference to the Mekong River, Lao P.D.R. MSc thesis, University of Victoria, British Columbia, Canada.

Stacey, P.J. \& Arnold, P.W. (1999) Orcaella brevirostris. Mammalian Species, 616, 1-8.

Tas'an \& Leatherwood, S. (1984) Cetaceans live-captured for Jaya Ancol Oceanarium, Djakarta, 1974-1982. Reports of the International Whaling Commission, 34, 485-489.

\section{Appendices 1-2}

The appendices for this article are available online at http:/ /journals.cambridge.org

\section{Biographical sketches}

Daniëlle Kreb studied freshwater and coastal Irrawaddy dolphins in East Kalimantan during 1999-2002, and in 2000 she became scientific adviser to the NGO Yayasan Konservasi RASI (Conservation Foundation for Rare Aquatic Species of Indonesia) in East Kalimantan and developed an ongoing conservation programme, in cooperation with the local government, to protect the freshwater dolphins and their habitat. She continues to carry out research and conservation work on cetaceans and protection of wildlife and habitats in Asia.

Budiono is interested in the study and protection of a wide range of animal species. In East Kalimantan he has studied lesser adjutant birds, Siamese crocodiles, dugongs and coastal and oceanic dolphins. He serves as the director of the NGO Yayasan Konservasi RASI and has been implementing the Pesut Mahakam Conservation Program with a special focus on awareness campaigns. 